medRxiv preprint doi: https://doi.org/10.1101/2021.03.17.21253610; this version posted March 17, 2021. The copyright holder for this preprint (which was not certified by peer review) is the author/funder, who has granted medRxiv a license to display the preprint in

All rights reserved. No reuse allowed without permission.

\title{
Characteristics and risk factors for SARS-CoV-2 among children in Italy: a cross-sectional study in 20 pediatric centers
}

Marzia Lazzerini $\mathrm{PhD}^{1}$, Idanna Sforzi $\mathrm{MD}^{2}$, Sandra Trapani $\mathrm{PhD}^{3}$, Paolo Biban $\mathrm{MD}^{4}$, Davide Silvagni MD , Ilaria Mariani MSc ${ }^{1}$, Giovanna Villa $M D^{5}$, Jessica Tibaldi $M^{5}$, Luca Bertacca $M D^{6}$, Enrico Felici $M D^{7}$, Giuseppina Perricone $\mathrm{MD}^{7}$, Roberta Parrino $\mathrm{MD}^{8}$, Claudia Gioè $\mathrm{MD}^{9}$, Sara Lega $\mathrm{MD}^{1}$, Mariasole Conte $\mathrm{MD}^{1}$, Federico

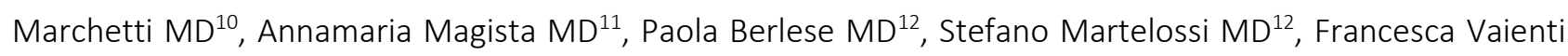
$M^{13}$, Enrico Valletta $\mathrm{MD}^{13}$, Margherita Mauro MD ${ }^{14}$, Roberto Dall'Amico $\mathrm{MD}^{14}$, Silvia Fasoli MD ${ }^{15}$, Antonio Gatto $\mathrm{MD}^{16}$, Antonio Chiaretti $\mathrm{MD}^{16}$, Danica Dragovic $\mathrm{MD}^{17}$, Paola Pascolo $\mathrm{MD}^{17}$, Chiara Pilotto $\mathrm{MD}^{18}$, Ilaria Liguoro $\mathrm{MD}^{18}$, Elisabetta Miorin $\mathrm{MD}^{19}$, Francesca Saretta $\mathrm{MD}^{19}$, Gianluca Trobia MD ${ }^{20}$, Antonella Di Stefano $M D^{20}$, Azzurra Orlandi MD²1, Fabio Cardinale MD ${ }^{21}$, Riccardo Lubrano MD ${ }^{22}$, Alessia Testa MD²2, Marco Binotti MD ${ }^{23}$, Valentina Moressa MD' , Egidio Barbi MD ${ }^{1,24}$ Benedetta Armocida MD ${ }^{1}$ on behalf of COVID-19 Italian Pediatric Study Network.

1. Institute for Maternal and Child Health - IRCCS "Burlo Garofolo" - Trieste, Italy

2. Department of Pediatric Emergency Medicine and Trauma Center, Meyer Children's University Hospital, Viale Pieraccini 24, 50139, Florence, Italy

3. Department of Health Sciences and Meyer Children's University Hospital, Viale Pieraccini 24, 50139, Florence, Italy

4. Department of Neonatal and Paediatric Critical Care, Verona University Hospital, Verona Italy

5. Pediatric Emergency Unit, IRCCS Gaslini Children's Hospital, Genoa, Italy

6. Pediatric Emergency Unit and Department of Pediatric and Neonatology, Misericordia Hospital, Grosseto, Italy

7. Pediatric and Pediatric Emergency Unit, The Children Hospital, AO SS Antonio e Biagio e Cesare Arrigo, Alessandria, Italy

8. Pediatria d'Urgenza e Pronto Soccorso P.O.G. Di Cristina, Palermo, Italy

9. Pediatric Infectious diseases, P.O.G. Di Cristina, Palermo, Italy

10. Department of Pediatrics, Ravenna Hospital, Ravenna, Italy

11. Department of Pediatrics, Community Pediatrics, Ravenna, Italy

12. Department of Pediatrics, Treviso Hospital, Treviso, Italy

13. Pediatric Department, G.B. Morgagni-L. Pierantoni Hospital, Forlì, Italy

14. Department of Pediatrics and Neonatology, Santa Maria degli Angeli Hospital, Pordenone, Italy




medRxiv preprint doi: https://doi.org/10.1101/2021.03.17.21253610; this version posted March 17, 2021. The copyright holder for this preprint (which was not certified by peer review) is the author/funder, who has granted medRxiv a license to display the preprint in All rights reserved. No reuse allowed without permission.

\footnotetext{
16. Department of Woman and Child Health and Public Health, Fondazione Policlinico Universitario A. Gemelli IRCCS, Rome, Italy

17. Pediatric Department, San Polo Hospital, ASUGI, Monfalcone (GO), Italy

18. Division of Paediatrics, Department of Medicine DAME, Academic Hospital Santa Maria della Misericordia, University of Udine, Udine, Italy

19. Department of Pediatrics, Latisana-Palmanova, ASUFC, Udine, Italy

20. Pediatric and Pediatric Emergency Room Unit Cannizzaro Emergency Hospital Catania, Italy

21. Giovanni XXIII Pediatric Hospital, Department of Pediatrics, University of Bari, Bari, Italy

22. Department of Pediatrics Sapienza University of Rome, Santa Maria Goretti Hospital, Latina, Italy

23. Neonatal and Pediatric Intensive Care Unit, Maggiore della Carità University Hospital, Novara, Italy

24. University of Trieste, Trieste, Italy
}

\section{corresponding author}

Marzia Lazzerini DTMH, MSc, PhD

WHO Collaborating Centre for Maternal and Child Health

Institute for Maternal and Child Health IRCCS Burlo Garofolo

Via dell'Istria 65/1, 34137, Trieste, ITALY

marzia.lazzerini@burlo.trieste.it 
medRxiv preprint doi: https://doi.org/10.1101/2021.03.17.21253610; this version posted March 17, 2021. The copyright holder for this preprint (which was not certified by peer review) is the author/funder, who has granted medRxiv a license to display the preprint in All rights reserved. No reuse allowed without permission.

ABSTRACT (250)

\section{Background}

No study has described factors associated with COVID-19 diagnosis in children.

\section{Aim}

Describe characteristics and risk factors for COVID-19 diagnosis in children tested in 20 pediatric centers across Italy.

\section{Methods}

Cases aged 0-18 years tested for SARS-CoV-2 between February 23 and May 242020 were included. Our primary analysis focused on children tested because of COVID-19 suggestive symptoms.

\section{Results}

Among 2494 children tested for SARS-CoV-2, 2148 (86.1\%) had symptoms suggestive of COVID-19. Clinical presentation of SARS-CoV-2 included - beside fever (82.4\%) and respiratory signs or symptoms (60.4\%) - also gastrointestinal (18.2\%), neurological (18.9\%), cutaneous (3.8\%) and other flu-like presentations (17.8\%). In multivariate analysis, factors significantly associated with SARS-CoV2 were: exposure history (adjusted OR 39.83 95\% Cl 17.52-90.55 p<0.0001), cardiac disease (adjusted OR $3.1095 \% \mathrm{Cl}$ 1.19- 5.02 p<0.0001), fever (adjusted OR $3.05 \%$ 95\% Cl 1.67-5.58 p=0.0003), and anosmia/ageusia (OR 4.08 95\% Cl 1.69 -9.84 p=0.002). Among 190 (7.6\%) children diagnosed with SARS-CoV-2, only four (2.1\%) required respiratory support and two (1.1\%) were admitted in ICU, while $100 \%$ recovered.

\section{Conclusion}

Recommendations for SARS-CoV-2 testing in children should be updated based on the evidence of broader clinical features. Exposure history, fever, and anosmia/ageusia are strong risk factors for COVID-19 in children, while other symptoms don't seem helping discriminating in between the SARSCoV-2 positive and the negative cases. This study confirm that COVID-19 is a mild disease in the general population of children in Italy. Further studies are needed to understand the risk, clinical spectrum and outcomes of COVID-19 in children with specific preexisting conditions. 
medRxiv preprint doi: https://doi.org/10.1101/2021.03.17.21253610; this version posted March 17, 2021. The copyright holder for this preprint (which was not certified by peer review) is the author/funder, who has granted medRxiv a license to display the preprint in All rights reserved. No reuse allowed without permission.

\section{INTRODUCTION}

The worldwide outbreak of severe acute respiratory syndrome coronavirus 2 (SARS-CoV-2), which emerged in Wuhan China in December 2019, rapidly affected Italy [1]. The first confirmed cases of coronavirus disease (COVID-19) in Italy were diagnosed on January 29, 2020. The Italian government declared a "state of emergency" by 31 $1^{\text {st }}$ January 2020 [2], and by 24 $4^{\text {th }}$ May 2020 a total of 229.858 cases of COVID-19 had been diagnosed across the country [3].

From the very beginning of the pandemic, data suggested that children are less affected than adults by COVID-19 [4-10]. However, timely diagnosis of COVID-19 is not only important for the single individual; it is crucial to prevent the spread of the pandemic. A better understanding of the predictors of positive SARS-CoV-2 test results may facilitate timely case finding and contact tracing and thus largely contribute to control the pandemic. It may also improve organization of care in settings were diagnostic facilities are available but still require a considerable processing time, where diagnostic facilities are lacking, and where diagnosis, in absence of other tools, may need to be based on clinical features alone.

Several systematic reviews have so far synthetized the clinical features and outcomes of pediatric cases with a confirmed infection by SARS-CoV-2 [11-17], but none published study yet explored the risk factors associated with a positive diagnosis of "COVID 19" among children undergoing a diagnostic test. It is currently unknown whether risk factors explored in adults [18-21] - such as exposure history, obesity, Iymphocytopenia, or ground glass opacity at lung X-ray [19] - apply for children. So far, only one unpublished report analyzed variables associated with increased odds of SARS-CoV-2 diagnosis in the pediatric population, but the sample was very small (77 cases) and the cases, retrospectively enrolled among hospitalized children, were not representative of the general pediatric population tested for SARS-CoV-2 [22].

This study aimed at describing the characteristics of pediatric patients tested for SARS-CoV-2 during the early phase of the pandemic in 20 centers across Italy, and at exploring risk factors associated with positive diagnosis of COVID-19. The sample was divided in the followings subgroups of children: a) children tested because of symptoms suggestive of COVID-19; b) asymptomatic children tested 
medRxiv preprint doi: https://doi.org/10.1101/2021.03.17.21253610; this version posted March 17, 2021. The copyright holder for this preprint (which was not certified by peer review) is the author/funder, who has granted medRxiv a license to display the preprint in All rights reserved. No reuse allowed without permission.

because of contact with a COVID-19 positive case; c) hospitalized children tested because of hospital screening programs.

\section{METHODS}

\section{Study designs and participants}

This cross-sectional study is reported according to STROBE guidelines [23]. Data were collected through a collaborative research network coordinated by the World Health Organization (WHO) Collaborating Center in Maternal and Child health of the Institute for Maternal and Child Health IRCCS Burlo Garofolo, Trieste, Italy. Cases aged 0-18 years tested for SARS-CoV-2 in the period between February 23 and May 24, 2020 in any of the 20 pediatric centers participating in the network were included in the study.

National recommendations on SARS-CoV-2 testing did not change during the study period, and indicated testing for: 1) contacts of COVID-19 positive cases; 2) cases of severe acute respiratory distress syndrome; 3 ) cases with either fever, cough or difficulty breathing and absence of another etiology that could fully explain the clinical presentation [24]. In addition, based on the local epidemiology and on emerging evidence on COVID-19 [25-27], some facilities implemented local policies of testing all children hospitalized and/or children with gastrointestinal or cutaneous symptoms, such as vasculitis, during the study period.

SARS-CoV-2 infection was diagnosed, in line with national recommendations, using nasal or nasopharyngeal swab specimens collected by trained personnel, and tested for SARS-CoV-2 nucleic acid in regional referral laboratories using WHO-recommended real-time reverse-transcriptase polymerase-chain-reaction (RT-PCR) assays.

\section{Data collection and management}

Data were collected with a standardized, field-tested on-line anonymous form, previously utilized for another study [12], and further optimized and adapted for the purpose of this study. The form collected variables to classify children in the following pre-defined categories: a) children tested because of symptoms suggestive of COVID-19; b) asymptomatic children tested because of contact 
medRxiv preprint doi: https://doi.org/10.1101/2021.03.17.21253610; this version posted March 17, 2021. The copyright holder for this preprint (which was not certified by peer review) is the author/funder, who has granted medRxiv a license to display the preprint in All rights reserved. No reuse allowed without permission.

with a COVID-19 positive case; c) hospitalized children tested because of hospital screening programs. It included information on socio-demographic and clinical characteristics, diagnostic examinations, type of treatments, and outcomes. Both closed and open questions were utilized. Data were obtained from official medical records and entered in the form by clinical staff in charge of case management at each facility level. Information for health workers on how to complete the form was embedded in the form itself. Data collection forms where checked in real time for internal consistency or missing data by trained personnel. Additional cross-check and data cleaning were conducted before data analysis by two expert biostatisticians (IM, BA).

\section{Study variables}

We included in this study socio-demographic and clinical characteristics, diagnostic examinations, type of treatments, and outcomes variables. For children tested because of symptoms suggestive of COVID-19, disease severity was classified using a pre-defined objective criterion adapted from previously published classification [12], as reported in Supplementary Table 1. Tachypnea and tachycardia where defined as detailed in Supplementary Table 2. The outcome variable for multivariate analysis was testing positive for SARS-CoV-2.

\section{Statistical analysis}

Categorical variables were reported as absolute numbers and percentages. Continuous variables were expressed as means and standard deviations (SD) or as median and inter-quartile ranges (IQR), if not normally distributed. We tested for associations between individual covariates and the outcome of a positive SARS-CoV-2 swab using $\chi^{2}$ test or Fisher's exact test, as appropriate. Variables with a significant univariate relationship with the outcome, available in the whole sample, unless collinear, were included in a generalized estimating equations (GEE) logistic regression model using a compound symmetry covariance structure within centers. The GEE model accounts for correlation between patients who refer to the same center. We performed separate analyses in the three subgroups: a) children tested because of symptoms suggestive of COVID-19; b) asymptomatic children tested because of a contact with a COVID-19 positive case; c) hospitalized children tested because of hospital screening programs. The analyses on children tested because of symptoms suggestive of COVID-19 were predefined as our primary analyses, while the analyses in the other two subgroups were considered secondary analyses. An exploratory subgroup analysis was performed on 
medRxiv preprint doi: https://doi.org/10.1101/2021.03.17.21253610; this version posted March 17, 2021. The copyright holder for this preprint (which was not certified by peer review) is the author/funder, who has granted medRxiv a license to display the preprint in All rights reserved. No reuse allowed without permission.

disease severity by age group and sex in patients with symptoms suggestive of COVID-19. We also performed secondary analyses to describe variation across centers in the rate of children with positive SARS-CoV-2- testing. The significance level was set at 0.05 (two-tailed test). Data were analyzed with STATA 14 and SAS 9.4.

\section{Ethical considerations}

The study was approved by the Institutional Review Board of the Institute for Maternal and Child Health IRCCS Burlo Garofolo, Trieste, Italy (reference number 01/2020 25.03.2020). Data were collected in an anonymous way, analyzed and reported only in aggregate form. Given the purely descriptive and retrospective nature of the study, informed consent was waived.

\section{RESULTS}

During the study period, 2494 children were tested for SARS-CoV-2 across 20 centers (Figure 1). Geographical case distribution is depicted in Supplementary Figure 1. Out of the total sample, 2148 (86.1\%) children were tested because of symptoms suggestive of COVID-19; 52 (2.1\%) asymptomatic children were tested because of contact with a COVID-19 positive case; 294 (11.8\%) children were tested within hospital screening programs. Among all the tested children, 190 (7.6\%) resulted positive. The percentage of positive cases was significantly higher in those tested because of a COVID19 positive contact (rate of COVID-19 positive 51.9\%) than in those tested because of symptoms (rate of COVID-19 positive $7.4 \%, p<0.0001$ ) or in hospital screening programs (rate of COVID-19 positive $2.1 \%, p<0.0001$ ) (Figure 1).

Figure 1. Study flow diagram

The clinical presentations of SARS-CoV-2 positive cases tested because of symptoms included besides fever and/or respiratory signs or symptoms - gastrointestinal, neurological, and dermatological manifestations and other flu-like features (Figure 2). Specifically, 131 children (82.4\%) had fever, which presented as the only symptom in 26 (25.2\%) and 96 (60.4\%) had respiratory signs/symptoms, which presented alone in nine (5.7\%). Neurological symptoms - such as convulsion, 
medRxiv preprint doi: https://doi.org/10.1101/2021.03.17.21253610; this version posted March 17, 2021. The copyright holder for this preprint (which was not certified by peer review) is the author/funder, who has granted medRxiv a license to display the preprint in All rights reserved. No reuse allowed without permission.

irritability, headache, anosmia/ageusia- were observed in 30 (18.9\%), in one child as the only symptom. Non-specific flu-like symptoms, such as muscular-articular pains, nausea, poor appetite, were reported in 27 (17.0\%), always in combination with other clinical signs. Six children were tested due to cutaneous signs such as vasculitis and pseudo-chilblains on fingertips and toes, always in association with other symptoms of any type (either fever, respiratory, neurological, flu-like or gastrointestinal).

Figure 2. Clinical presentation of SARS-CoV-2 positive children

Abbreviations: GI = gastro-intestinal; Resp = respiratory; Neuro = Neurological.

When comparing children based on the results of swab testing (Table 1), children SARS-CoV-2 positive were more often in the stratum of 10 to 18 years compared to the SARS-CoV-2 negative $(54.1 \%$ vs $26.0 \%, p<0.001)$. No difference by sex was observed. A history of COVID-19 positive contact was strongly associated with an increased risk of positive swab (79.2\% vs $6.1 \%, p<0.001)$. Similarly, having a relative with respiratory symptoms was strongly associated with SARS-CoV-2 positive test results (72.3\% vs $11.5 \% \mathrm{p}<0.001$ ). Both positive and negative children had a non-negligible rate of comorbidities ( $17.6 \%$ vs $16.4 \%, p=0.7$ ), with cardiac diseases being slightly more frequent in the group testing positive for SARS-CoV-2 (5.7\% vs $2.1 \% \mathrm{p}=0.005)$.

Table 1. Socio-demographic characteristics of children tested because of symptoms suggestive for COVID-19

\begin{tabular}{|c|c|c|c|c|c|}
\hline & \multicolumn{2}{|c|}{$\begin{array}{c}\text { Positive swab } \\
\quad \mathrm{N}=159\end{array}$} & \multicolumn{2}{|c|}{$\begin{array}{l}\text { Negative swab } \\
\qquad N=1989\end{array}$} & \multirow[b]{2}{*}{$p$-values } \\
\hline & $\mathrm{n}$ & $\%$ & $\mathrm{n}$ & $\%$ & \\
\hline \multicolumn{6}{|l|}{ Age groups } \\
\hline$<6$ months & 19 & 12.0 & 159 & 8.0 & 0.082 \\
\hline 6-24 months & 17 & 10.7 & 472 & 23.7 & $<0.001$ \\
\hline $2-9$ years & 37 & 23.3 & 836 & 42.0 & $<0.001$ \\
\hline $10-18$ years & 86 & 54.1 & 517 & 26.0 & $<0.001$ \\
\hline Missing & 0 & 0 & 5 & 0.3 & 1.000 \\
\hline \multicolumn{6}{|l|}{ Sex } \\
\hline Male & 77 & 48.4 & 1108 & 55.7 & 0.076 \\
\hline
\end{tabular}


medRxiv preprint doi: https://doi.org/10.1101/2021.03.17.21253610; this version posted March 17, 2021. The copyright holder for this preprint (which was not certified by peer review) is the author/funder, who has granted medRxiv a license to display the preprint in All rights reserved. No reuse allowed without permission.

\begin{tabular}{|c|c|c|c|c|c|}
\hline Female & 82 & 51.6 & 880 & 44.2 & 0.074 \\
\hline Missing & 0 & 0 & 1 & 0.1 & 1.000 \\
\hline Contact with COVID-19 positive & 126 & 79.2 & 122 & 6.1 & $<0.001$ \\
\hline Relatives with respiratory symptoms & 115 & 72.3 & 229 & 11.5 & $<0.001$ \\
\hline Any co-morbidity & 28 & 17.6 & 327 & 16.4 & 0.702 \\
\hline \multicolumn{6}{|l|}{ Type of comorbidities } \\
\hline $\begin{array}{l}\text { Malformation, disabilities, } \\
\text { neuromuscular diseases }\end{array}$ & 5 & 3.1 & 81 & 4.1 & 0.566 \\
\hline Cardiac diseases & 9 & 5.7 & 42 & 2.1 & 0.005 \\
\hline Asthma & 6 & 3.8 & 60 & 3.0 & 0.593 \\
\hline Others Respiratory diseases/conditions & 0 & 0 & 17 & 0.9 & 0.631 \\
\hline Primary immunodeficiencies & 1 & 0.6 & 12 & 0.6 & 1.000 \\
\hline Secondary immunodeficiencies & 1 & 0.6 & 41 & 2.1 & 0.365 \\
\hline Obesity & 1 & 0.6 & 12 & 0.6 & 1.000 \\
\hline Diabetes & 1 & 0.6 & 2 & 0.1 & 0.206 \\
\hline Psychiatric disorders & 1 & 0.6 & 21 & 1.1 & 1.000 \\
\hline Other & 9 & 5.7 & 97 & 4.9 & 0.659 \\
\hline
\end{tabular}

When compared for disease severity at presentation (Table 2), there were no significant differences between children who were SARS-CoV-2 positive and those negative, with most cases having a mild presentation (78\% and $70.8 \%$, respectively, $\mathrm{p}=0.053$ ) and an equal number of cases having a severe (3.1\% vs $6.7 \%, p=0.091)$ or critical presentation $(1.3 \%$ vs $1.0 \%, p=0.665)$ in each group.

Fever was highly prevalent in both groups, significantly more in SARS-CoV-2 positive children (82.4\% vs $68.1 \%, p<0.001)$. Respiratory symptoms were highly prevalent in both groups $(60.4 \%$ vs $66.6 \%$, $p=0.110$ ) with some differences: dry cough was more frequent in the group of SARS-CoV-2 positives (32.1\% vs $22.7 \%, p=0.007$ ), whereas sore throat and strep throat were less frequent in this group compared to the negatives ( $22.6 \%$ vs $44.3 \%, p<0.001$ and $1.3 \%$ vs $5.3 \%, p=0.024$ respectively). Respiratory distress was less frequent in the group testing positive for SARS-CoV-2 than in the group testing negative, although the difference was not statistically significant $(7.5 \%$ vs $12.8 \%, p=0.052)$. Gastrointestinal symptoms ( $18.2 \%$ vs $28.9 \%, p=0.004$ ), and other symptoms ( $14.5 \%$ vs $26.6 \%$, $p=0.001$ ) were significantly less frequent in the group of SARS-CoV-2 positives, while the opposite was true of neurological symptoms $(18.9 \%$ vs $8.8 \%, p<0.001)$ and muscle or joint pains $(11.3 \%$ vs $3.6 \%, p<0.001)$. 
medRxiv preprint doi: https://doi.org/10.1101/2021.03.17.21253610; this version posted March 17, 2021. The copyright holder for this preprint (which was not certified by peer review) is the author/funder, who has granted medRxiv a license to display the preprint in perpetuity.

All rights reserved. No reuse allowed without permission.

Vital parameters, as well as oxygen saturation levels and lung auscultation were not significantly different between the two groups. Lymphocytopenia was significantly more frequent in the SARSCoV-2 positive group ( $34.0 \%$ vs $13.5 \%$, p<0.001), while elevated C-reactive protein was more frequent in the SARS-CoV-2 negative group (58.0\% vs $77.5 \%, p=0.002$ ). Findings at chest-X-ray, lung ultrasound and lung CT scan were not significantly different among the two groups, with equal prevalence of ground glass opacities (respectively $25.9 \%$ vs $22.7 \%, p=0.7,40.0 \%$ vs $51.7 \% p=0.67$ ).

The frequencies of hospitalized cases $(28.3 \%$ vs $30.3 \%, p=0.60)$ and those admitted to intensive care (ICU) $(1.3 \%$ vs $0.6 \%, p=0.25)$ were not significantly different between the SARS-CoV-2 positive and negative children. Need and type of respiratory support was also not significantly different. Final outcomes did not differ between groups, although in the SARS-CoV-2 negative group one death was observed.

Table 2. Clinical presentation and outcomes of children tested because of symptoms suggestive for COVID-19

\begin{tabular}{|c|c|c|c|c|c|}
\hline & \multicolumn{2}{|c|}{$\begin{array}{c}\text { Positive swab } \\
\quad N=159\end{array}$} & \multicolumn{2}{|c|}{$\begin{array}{c}\text { Negative swab } \\
\quad \mathrm{N}=1989\end{array}$} & \multirow[b]{2}{*}{ p-values } \\
\hline & $\mathrm{n}$ & $\%$ & $\mathrm{n}$ & $\%$ & \\
\hline \multicolumn{6}{|c|}{ Disease severity at presentation } \\
\hline Asymptomatic & 8 & 5.0 & 125 & 6.3 & 0.528 \\
\hline Mild & 124 & 78.0 & 1408 & 70.8 & 0.053 \\
\hline Moderate & 20 & 12.6 & 304 & 15.3 & 0.359 \\
\hline Severe & 5 & 3.1 & 133 & 6.7 & 0.091 \\
\hline Critical & 2 & 1.3 & 19 & 1.0 & 0.665 \\
\hline \multicolumn{6}{|c|}{ Symptoms and signs at presentation } \\
\hline Fever & 131 & 82.4 & 1355 & 68.1 & $<0.001$ \\
\hline Respiratory symptoms, any & 96 & 60.4 & 1325 & 66.6 & 0.110 \\
\hline Respiratory distress & 12 & 7.5 & 255 & 12.8 & 0.052 \\
\hline Rhinorrhea & 32 & 20.1 & 372 & 18.7 & 0.659 \\
\hline Dry cough & 51 & 32.1 & 452 & 22.7 & 0.007 \\
\hline Productive cough & 7 & 4.4 & 185 & 9.3 & 0.037 \\
\hline Sore throat & 36 & 22.6 & 881 & 44.3 & $<0.001$ \\
\hline
\end{tabular}


medRxiv preprint doi: https://doi.org/10.1101/2021.03.17.21253610; this version posted March 17, 2021. The copyright holder for this preprint (which was not certified by peer review) is the author/funder, who has granted medRxiv a license to display the preprint in perpetuity.

All rights reserved. No reuse allowed without permission.

\begin{tabular}{|c|c|c|c|c|c|}
\hline Strep throat & 2 & 1.3 & 106 & 5.3 & 0.024 \\
\hline Conjunctivitis & 8 & 5.0 & 60 & 3.0 & 0.163 \\
\hline Apnea & 0 & 0 & 4 & 0.2 & 1.000 \\
\hline Thoracic pain & 6 & 3.8 & 44 & 2.2 & 0.209 \\
\hline Gastrointestinal symptoms, any & 29 & 18.2 & 574 & 28.9 & 0.004 \\
\hline Vomiting & 16 & 10.1 & 365 & 18.3 & 0.009 \\
\hline Diarrhea & 18 & 11.3 & 293 & 14.7 & 0.240 \\
\hline Neurological symptoms, any & 30 & 18.9 & 175 & 8.8 & $<0.001$ \\
\hline Asthenia & 10 & 6.3 & 38 & 1.9 & $<0.001$ \\
\hline Headache & 13 & 8.2 & 79 & 4.0 & 0.012 \\
\hline Anosmia/ageusia & 13 & 8.2 & 10 & 0.5 & $<0.001$ \\
\hline Convulsion & 2 & 1.3 & 49 & 2.5 & 0.583 \\
\hline Hyperactivity & 1 & 0.6 & 12 & 0.6 & 1.000 \\
\hline Cutaneous presentations, any & 6 & 3.8 & 159 & 8.0 & 0.054 \\
\hline Skin manifestations & 6 & 3.8 & 158 & 7.9 & 0.057 \\
\hline Vasculitis & 0 & 0 & 11 & 0.6 & 1.000 \\
\hline Unspecific flu-like presentations, any & 27 & 17.0 & 303 & 15.2 & 0.557 \\
\hline Muscle or joint pains & 18 & 11.3 & 71 & 3.6 & $<0.001$ \\
\hline Nausea & 0 & 0 & 13 & 0.7 & 0.616 \\
\hline Inappetence & 15 & 9.4 & 237 & 11.9 & 0.349 \\
\hline Lymphadenitis & 8 & 5.0 & 158 & 7.9 & 0.186 \\
\hline Other symptoms, any & 23 & 14.5 & 528 & 26.6 & 0.001 \\
\hline Abdominal pains & 11 & 6.9 & 269 & 13.5 & 0.017 \\
\hline $\begin{array}{l}\text { Oral manifestations } \\
\text { (gingivostomatitis, aphthae) }\end{array}$ & 2 & 1.3 & 54 & 2.7 & 0.433 \\
\hline Dental problems & 1 & 0.6 & 6 & 0.3 & 0.417 \\
\hline Urogenital disorders & 0 & 0 & 10 & 0.5 & 1.000 \\
\hline Ear problems & 0 & 0 & 32 & 1.6 & 0.166 \\
\hline Others & 3 & 1.9 & 41 & 2.1 & 1.000 \\
\hline \multicolumn{6}{|l|}{ Vital parameters at presentation } \\
\hline Tachycardia & $12 / 61$ & 19.7 & $294 / 1489$ & 19.7 & 0.989 \\
\hline Tachypnea & $4 / 34$ & 11.8 & $187 / 827$ & 22.6 & 0.204 \\
\hline $\begin{array}{l}\text { Oxygen saturation level at } \\
\text { presentation }\end{array}$ & & & & & \\
\hline
\end{tabular}


medRxiv preprint doi: https://doi.org/10.1101/2021.03.17.21253610; this version posted March 17, 2021. The copyright holder for this preprint (which was not certified by peer review) is the author/funder, who has granted medRxiv a license to display the preprint in perpetuity.

All rights reserved. No reuse allowed without permission.

\begin{tabular}{|c|c|c|c|c|c|}
\hline $91-92$ & $2 / 66$ & 3.0 & $15 / 1575$ & 0.1 & 0.147 \\
\hline$\leq 90$ & $1 / 66$ & 1.5 & $21 / 1575$ & 1.3 & 0.597 \\
\hline \multicolumn{6}{|l|}{ Clinical examination at presentation } \\
\hline \multicolumn{6}{|l|}{ Lungs auscultations } \\
\hline Negative & $69 / 86$ & 80.2 & $1486 / 1826$ & 81.3 & 0.810 \\
\hline Crackles & $4 / 86$ & 4.7 & $186 / 1826$ & 10.2 & 0.099 \\
\hline Wheezing & $3 / 86$ & 3.5 & $120 / 1826$ & 5.6 & 0.366 \\
\hline Absent breath sounds & $4 / 86$ & 4.7 & $111 / 1826$ & 6.1 & 0.816 \\
\hline \multicolumn{6}{|l|}{ Laboratory test ${ }^{1}$} \\
\hline White blood cell count $<5.5\left(\times 10^{9} / \mathrm{L}\right)$ & $17 / 50$ & 34.0 & 109/809 & 13.5 & $<0.001$ \\
\hline Lymphocyte count <1.2 (×109/L) & $8 / 41$ & 19.5 & $75 / 559$ & 13.4 & 0.275 \\
\hline Neutrophil <1.50 $\left(\times 10^{9} / L\right)$ & $6 / 47$ & 12.8 & $50 / 743$ & 6.7 & 0.118 \\
\hline C-reactive protein > $1 \mathrm{gr} / \mathrm{dl}$ & $29 / 50$ & 58.0 & $589 / 760$ & 77.5 & 0.002 \\
\hline $\begin{array}{l}\text { Erythrocyte sedimentation rate }>20 \\
\mathrm{~mm} / \mathrm{h}\end{array}$ & $2 / 4$ & 50.0 & $34 / 64$ & 53.3 & 1.000 \\
\hline $\begin{array}{l}\text { Aspartate aminotransferase }>50 \\
(\mathrm{U} / \mathrm{L})\end{array}$ & $7 / 35$ & 20.0 & $56 / 434$ & 12.9 & 0.234 \\
\hline Alanine aminotransferase $>45(\mathrm{U} / \mathrm{L})$ & $4 / 46$ & 8.7 & $74 / 692$ & 10.7 & 0.808 \\
\hline D dimer $>0.5(\mu \mathrm{g} / \mathrm{mL})$ & $2 / 4$ & 50.0 & $24 / 46$ & 52.2 & 1.000 \\
\hline Chest X-ray & 27 & 17.0 & 313 & 15.7 & 0.679 \\
\hline Negative & $8 / 27$ & 29.6 & $106 / 313$ & 33.9 & 0.655 \\
\hline Ground glass opacities & $7 / 27$ & 25.9 & $71 / 313$ & 22.7 & 0.701 \\
\hline Focal consolidation & $3 / 27$ & 11.1 & $77 / 313$ & 24.6 & 0.155 \\
\hline Other description & $9 / 27$ & 33.3 & $59 / 313$ & 18.8 & 0.071 \\
\hline Lung ultrasound & 5 & 3.1 & 58 & 2.9 & 0.806 \\
\hline Negative & $1 / 5$ & 20.0 & $18 / 58$ & 38.0 & 1.000 \\
\hline B-lines in various pattern & $2 / 5$ & 40.0 & $30 / 58$ & 51.7 & 0.672 \\
\hline Focal consolidation & 0 & 0 & $5 / 58$ & 8.6 & 1.000 \\
\hline Other description & $1 / 5$ & 20.0 & $1 / 58$ & 1.7 & 0.154 \\
\hline Lung CT scan & 5 & 3.1 & 13 & 0.7 & 0.008 \\
\hline Negative & $0 / 5$ & 0 & $2 / 13$ & 15.4 & 1.000 \\
\hline Ground glass opacities & $3 / 5$ & 60.0 & $6 / 13$ & 46.2 & 1.000 \\
\hline Focal consolidation & $1 / 5$ & 20.0 & $3 / 13$ & 23.1 & 1.000 \\
\hline Other description & $0 / 5$ & 0 & $2 / 13$ & 15.4 & 1.000 \\
\hline
\end{tabular}


medRxiv preprint doi: https://doi.org/10.1101/2021.03.17.21253610; this version posted March 17, 2021. The copyright holder for this preprint (which was not certified by peer review) is the author/funder, who has granted medRxiv a license to display the preprint in All rights reserved. No reuse allowed without permission.

\begin{tabular}{|l|c|c|c|c|c|}
\hline Hospitalised & 45 & 28.3 & 602 & 30.3 & 0.603 \\
\hline Respiratory support ${ }^{1}$ & 4 & 2.5 & 73 & 3.7 & 0.656 \\
Oxygen & $3 / 45$ & 6.7 & $54 / 602$ & 9.0 & 0.788 \\
High flow oxygen & $2 / 45$ & 4.4 & $19 / 602$ & 3.2 & 0.651 \\
Noninvasive ventilation & $1 / 45$ & 2.2 & $4 / 602$ & 0.7 & 0.303 \\
Mechanical ventilation & $0 / 45$ & 0 & $11 / 602$ & 1.8 & 1.000 \\
\hline Cases in ICU & 2 & 1.3 & 11 & 0.6 & 0.250 \\
\hline Outcome & & & & & 0.4 \\
Cured & 159 & 100 & 1981 & 99.6 & 0.500 \\
Referred & 0 & 0 & 7 & 0.4 & 1.000 \\
Dead & 0 & 0 & 1 & 0.460 \\
\hline
\end{tabular}

Abbreviations: ICU= intensive Care Unit

1 Note: available in a subsample of cases

\section{Multivariate analysis}

In multivariate analysis, factors significantly associated with testing positive for SARS-CoV-2 were: contact with COVID-19 positive patient (OR $39.8395 \% \mathrm{Cl} 17.52$ to $90.55 \mathrm{p}<0.0001$ ), preexisting cardiac disease (OR $3.1095 \% \mathrm{Cl} 1.19$ to $5.02 \mathrm{p}<0.0001$ ), fever (OR $3.05 \% 95 \% \mathrm{Cl} 1.67$ to 5.58 $p=0.0003$ ), and anosmia/ageusia (OR $4.0895 \% \mathrm{Cl} 1.69$ to $9.84 \mathrm{p}=0.002$ ) (Table 3). Age between 2-9 years was negatively associated with testing positive for COVID-19, when taking the group of 10-18 years as reference (OR $0.33 \mathrm{Cl} 0.22$ to $0.50 \mathrm{p}<0.0001)$.

\section{Table 3. Multivariate analysis}

\begin{tabular}{|l|c|c|}
\hline & Adjusted OR (95\% Cl) & P value \\
\hline Age groups & & 0.725 \\
6 months & $1.12(0.60-2.11)$ & 0.107 \\
2 -9 months & $0.43(0.15-1.20)$ & $<.0001$ \\
$10-18$ years & $0.33(0.22-0.50)$ & Reference \\
\hline Contact with COVID-19 positive & Reference & $<.0001$ \\
\hline Cardiac disease & $39.83(17.52-90.55)$ & $<.0001$ \\
\hline Fever & $3.10(1.19-5.02)$ & 0.0003 \\
\hline
\end{tabular}


medRxiv preprint doi: https://doi.org/10.1101/2021.03.17.21253610; this version posted March 17, 2021. The copyright holder for this preprint (which was not certified by peer review) is the author/funder, who has granted medRxiv a license to display the preprint in All rights reserved. No reuse allowed without permission.

\begin{tabular}{|l|c|c|}
\hline Dry cough & $1.31(0.87-2.01)$ & 0.199 \\
\hline Productive cough & $0.53(0.18-1.53)$ & 0.242 \\
\hline Sore throat & $0.54(0.29-1.03)$ & 0.063 \\
\hline Strep throat & $0.41(0.09-1.86)$ & 0.963 \\
\hline Vomiting & $1.01(0.68-1.50)$ & 0.911 \\
\hline Asthenia & $0.94(0.31-2.84)$ & 0.956 \\
\hline Headache & $0.98(0.52-1.87)$ & 0.124 \\
\hline Anosmia/ageusia & $4.08(1.69-9.84)$ & 0.882 \\
\hline Muscle or joint pain & $1.76(0.86-3.63)$ & \\
\hline Abdominal pains & $1.05(0.57-1.94)$ & \\
\hline
\end{tabular}

\section{Secondary analyses}

Additional details on the 190 children testing positive for SARS-CoV-2 are reported in Supplementary Table 3. Overall, 139 (73.1\%) children were cared for at home. The remaining were hospitalized in two types of wards: pediatric wards (55.6\%) and general COVID-19 wards (53.3\%). Cases treated with home care were either asymptomatic or had a mild or moderate presentation. Children received different types of treatments, with antibiotic, steroids and hydroxychloroquine being more frequently prescribed among hospitalized children (respectively $35.6 \%$ vs $10.5 \% p<0.001 ; 8.9 \%$ vs $0.0 \% p=0.006 ; 8.9 \%$ vs $0.0 \% p=0.006$ ), while antipyretics/analgesic were much more frequently used in home care management ( $2.2 \%$ vs $51.8 \%$ p $<0.001)$.

Socio-demographic, clinical characteristics and outcomes of children tested because of a COVID-19 positive contact and of those tested through hospital screening are reported in Supplementary Table 4. No significant difference was observed for any variable between the SARS-CoV-2 positives and the negatives in these two groups. None of the children positive for SARS-CoV-2 in these groups had respiratory distress, none required respiratory support, none were admitted in ICU, and all recovered.

No difference in disease severity were observed by age and sex, in children COVID -19 positive and symptoms suggestive of COVID-19 (Supplementary Table 5). 
medRxiv preprint doi: https://doi.org/10.1101/2021.03.17.21253610; this version posted March 17, 2021. The copyright holder for this preprint (which was not certified by peer review) is the author/funder, who has granted medRxiv a license to display the preprint in

All rights reserved. No reuse allowed without permission.

The rate of children testing positive for SARS-CoV-2 in each center was variable with an average rate of $9.17 \%(95 \% \mathrm{Cl} 0$ to 18.71 , Supplementary Figure 2). Specifically, in $17 / 20$ (85\%) centers the prevalence of COVID-19 positive swabs was below 15\%, in two centers it was in between $15 \%$ to $20 \%$, and in one center it was over $20 \%$.

\section{DISCUSSION}

This study adds to previous knowledge a description of characteristics and risk factors for SARS-CoV2 among children. Notably, the clinical presentation of children with SARS-CoV-2 includes different possible scenarios. Besides the typical clinical picture with fever and respiratory signs or symptoms, this study suggested that COVID-19 in children may have gastrointestinal, neurological or cutaneous presentations, either in combination with other presentations or alone. These results are in line with reports from rheumatologists and dermatologists [25,26], gastroenterologists [27], neurologists and psychiatrists $[28,29]$. Additionally, emerging findings from COVID-19 screening among categories of people at risk, such as health workers, indicate that the current guidelines for testing may risk missing many cases [30]. Furthermore, it is important to acknowledge that, because the recommendations on SARS-Cov-2 case identification [24,31] indicate testing only for cases with either fever or respiratory signs, the real prevalence of other presentations (e.g., gastrointestinal, neurological and cutaneous) may have gone underestimated in this study, as well as in other studies. Guidelines for SARS-COV-2 testing should be updated based on the evidence on clinical presentation of the disease in children and adults.

Our findings suggest that, in contrast with what has been observed in adults $[18,19]$, in children there are very few features which help differentiate those affected by SARS-Cov-2 from those with other conditions. Specifically, some of the features identified so far in the few existing studies as predicting factors for COVID-19 in adults - such as obesity, leucopenia, lymphocytopenia, ground glass opacity at X-ray, and having both lungs affected [19], were not confirmed in children. This seems plausible, considering the generally mild presentation of SARS-CoV-2 in the pediatric age compared to adults, and the large number of other viruses which can affect children resulting in clinical pictures very similar to COVID-19. 
medRxiv preprint doi: https://doi.org/10.1101/2021.03.17.21253610; this version posted March 17, 2021. The copyright holder for this preprint (which was not certified by peer review) is the author/funder, who has granted medRxiv a license to display the preprint in All rights reserved. No reuse allowed without permission.

Findings of this study indicate that a diagnosis of COVID-19 may be much more probable in those with contact with a person testing positive for SARS-Cov-2 (OR $39.8395 \% \mathrm{Cl} 17.52$ to 90.55), or with fever (OR $3.0595 \% \mathrm{Cl} 1.67$ to 5.58) or anosmia/ageusia (OR $4.0895 \% \mathrm{Cl} 1.69$ to $9.84 \mathrm{p}=0.002$ ). These results are in line with studies in adults $[19,28]$, and underscore the importance of testing all cases with exposure history and increased body temperature, as well as those with peculiar neurological signs.

Our findings related to young age as a protective factor (with children in the age range of 2-9 years being at lower risk of COVID-19 compared to reference group of $10-18$ years, OR $0.3395 \% \mathrm{Cl} 0.22$ to 0.50 ) and to presence of cardiac disease as a risk factor (OR $3.1095 \% \mathrm{Cl} 1.19$ to 5.02 ) are novel, and warrant further confirmation and identification of causal mechanisms. Interestingly, the rate of comorbidities among all children accessing the health system with a presentation suggestive of COVID-19 was relatively high $(355 / 2148,16.5 \%)$. Nevertheless, the only comorbidity found to be associated with positive testing for SARS- CoV-2 was preexisting cardiac diseases. Interestingly, preexisting chronic kidney disease was found to be a significant predictive factor for COVID-19 diagnosis in one large study at the primary care level in England, not specific to children [18]. These results should be confirmed in larger studies in children. More studies should also contribute to explore if other factors apparently important in adults [18] - such as ethnicity, living situation, deprivation, children with smoking parents, obesity - may increase the risk of COVID-19 in children in Italy as well as in other settings.

This study suggests that COVID-19 is a mild disease in children in Italy: among the 190 children diagnosed with SARS-CoV-2 in our study, 12 (6.3\%) had respiratory distress, only four (2.1\%) required respiratory support, only two (1.1\%) were admitted in ICU, and $100 \%$ recovered. These results are in line with surveillance data in Italy [32], and with previous reports on COVID-19 in children from different countries $[4-6,16,33,34]$. According to existing surveillance data from CDC, the number of deaths among children under 15 years of age with COVID-19 in United States was much lower than what was reported for children with seasonal influenzas in 2019-2020 (17 reported deaths for COVID19 compared to 182 influenza-associated pediatric deaths) [35,36]. In contrast, data from adults indicate that COVID-19 may be more severe than influenzas in this population [37]. 
medRxiv preprint doi: https://doi.org/10.1101/2021.03.17.21253610; this version posted March 17, 2021. The copyright holder for this preprint (which was not certified by peer review) is the author/funder, who has granted medRxiv a license to display the preprint in

All rights reserved. No reuse allowed without permission.

The sample of children hospitalized in this study is not negligible when compared with national data: at the end of the study period, Italian surveillance systems reported 227,204 confirmed SARS-CoV-2 cases in Italy, but only 123 hospitalized cases among children (i.e. age below 18 years) [32]. Our sample of 51 children hospitalized with COVID-19, thus, accounts for $41.4 \%$ of the total pediatric cases reported by national surveillance [32]. Clearly, larger prevalence studies as well as prospective longitudinal studies are needed to better understand the risk associated with COVID-19 in selected sub-populations of children at risk. Despite current preliminary evidence suggesting that even in children with underlying conditions - such as children with inflammatory bowel diseases [38], cancer [39], children in dialysis [40], and children with renal diseases in steroid treatment [41] - the risk of severe COVID-19 disease may be limited, much more solid data are needed.

This study highlights several interesting epidemiological findings, reporting the number of children tested in each center in the early phase of the pandemic and the rate of positivity. High heterogeneity across centers in the rate of positive SARS-CoV-2 testing is not surprising and may have multiple explanations. First, the epidemiology of the disease differs across Italy, where Regions in the North overall had a higher burden of cases compared to those in the South [42]. Second, case identification may have been affected by local protocols, testing capacities, and different implementation of testing recommendations, both at study start and over time. The number of total swabs per population has been reported as highly variable across Regions in Italy, and not always directly proportional to the incidence of COVID-19 disease, with considerable variations over time [43]. The implementation of case finding and contact tracing has been described as highly heterogenous in other countries [44] and would warrant further investigation to better interpret epidemiological curves. Epidemiological data on COVID-19, due also to limitations in the currently available technology for COVID-19 diagnosis (i.e., high rates of false negatives with nasal or nasopharyngeal swabs [45]) may not reflect the real incidence of the disease in each setting, and should, in general, be interpreted with extreme caution. Further studies should document knowledge, attitudes, and practices of case finding and contact tracing in Italy as well as in other settings. More accurate, acceptable, and sustainable tools are also needed for COVID-19 diagnosis.

Limitations of this study include the retrospective nature of data, possible selection bias toward more symptomatic cases due to the nature of the network, and the limitation in the technology currently available for COVID-19 diagnosis. Although the use of swabs is currently recommended as the "gold 
medRxiv preprint doi: https://doi.org/10.1101/2021.03.17.21253610; this version posted March 17, 2021. The copyright holder for this preprint (which was not certified by peer review) is the author/funder, who has granted medRxiv a license to display the preprint in All rights reserved. No reuse allowed without permission.

standard" for COVID-19 diagnosis, it has as major limitation of a high percentage of false negative cases [45]. Future studies, when better diagnostic tools will be available, should aim to confirm the observations of the present study. Strengths of this study include its pragmatic and descriptive nature, and the involvement of many pediatric centers in the national territory. More clinical and epidemiological studies are needed to further document the real incidence, presentation, risk factors and outcomes of children with COVID-19 infection in different pediatric subpopulations, to better characterize children at higher risk of the most severe forms of the disease. 
medRxiv preprint doi: https://doi.org/10.1101/2021.03.17.21253610; this version posted March 17, 2021. The copyright holder for this preprint (which was not certified by peer review) is the author/funder, who has granted medRxiv a license to display the preprint in

All rights reserved. No reuse allowed without permission.

\section{REFERENCES}

1. World Health Organization. Coronavirus disease (COVID-2019) situation reports 79. Available at (accessed on March 27, 2020) https://www.who.int/emergencies/diseases/novel-coronavirus2019/situation-reports

2. COVID-19. Situation in Italy. Available on http://www.salute.gov.it/portale/nuovocoronavirus/dettaglioContenutiNuovoCoronavirus.jsp?ling ua=italiano\&id=5351\&area=nuovoCoronavirus\&menu=vuoto (accessed May 28, 2020)

3. Ministero della Salute. COVID-19, i casi in Italia 24 maggio 2020. Aggiornamento nazionale 24 maggio 2020. Avallabile at

http://www.salute.gov.it/portale/nuovocoronavirus/dettaglioNotizieNuovoCoronavirus.jsp?lingua= italiano\&menu=notizie\& $p=$ dalministero\&id $=4807$ (accessed September 29, 2020)

4. Dong Y, Mo X, Hu Y, Qi X, Jiang F, Jiang Z, et al. Epidemiological Characteristics of 2143 Pediatric Patients With 2019 Coronavirus Disease in China. Pediatrics. 2020 Mar 16

5. Parri N, Magistà AM, Marchetti F, Cantoni B, Arrighini A, Romanengo $M$, et al. Characteristic of COVID-19 infection in pediatric patients: early findings from two Italian Pediatric Research Networks [published online ahead of print, 2020 Jun 3]. Eur J Pediatr. 2020;1-9. doi:10.1007/s00431-02003683-8)

6. Garazzino S, Montagnani C, Donà D, Meini A, Felici E, Vergine G, et al. Multicentre Italian study of SARS-CoV-2 infection in children and adolescents, preliminary data as at 10 April 2020. Euro Surveill. 2020;25(18):2000600. doi:10.2807/1560-7917.ES.2020.25.18.2000600

7. Tagarro A, Epalza C, Santos M, Sanz-Santaeufemia FJ, Otheo E, Moraleda C, et al. Screening and Severity of Coronavirus Disease 2019 (COVID-19) in Children in Madrid, Spain. JAMA Pediatr. Published online April 08, 2020. doi:10.1001/jamapediatrics.2020.1346

8. Zachariah P, Johnson CL, Halabi KC, Ahn D, Sen Al, Fischer A, et al. Epidemiology, Clinical Features, and Disease Severity in Patients With Coronavirus Disease 2019 (COVID-19) in a Children's Hospital in New York City, New York [published online ahead of print, 2020 Jun 3]. JAMA Pediatr. 2020;e202430. doi:10.1001/jamapediatrics.2020.2430

9. Götzinger F, Santiago-García B, Noguera-Julián A, Lanaspa M, Lancella L, Calò Carducci Fl, et al. COVID-19 in children and adolescents in Europe: a multinational, multicentre cohort study. Lancet Child Adolesc Health. 2020 Sep;4(9):653-661. doi: 10.1016/S2352-4642(20)30177-2. Epub 2020 Jun 25. PMID: 32593339; PMCID: PMC7316447.

10. Coronavirus Disease 2019 in Children - United States, February 12-April 2, 2020. MMWR Morb Mortal Wkly Rep. ePub: 6 April 2020. DOI: http://dx.doi.org/10.15585/mmwr.mm6914e4external icon

11. Castagnoli R, Votto M, Licari A, Brambilla I, Bruno R, Perlini S, et al. Severe Acute Respiratory Syndrome Coronavirus 2 (SARS-CoV-2) Infection in Children and Adolescents: A Systematic Review. JAMA Pediatr. Published online April 22, 2020. doi:10.1001/jamapediatrics.2020.1467

12. Hoang A, Chorath K, Moreira A, Evans M, Burmeister-Morton F, Burmeister F, et al. COVID-19 in 7780 pediatric patients: A systematic review. EClinicalMedicine. 2020 Jun 26;24:100433. doi: 10.1016/j.eclinm.2020.100433. PMID: 32766542; PMCID: PMC7318942.

13. Zimmermann P, Curtis N. Coronavirus Infections in Children Including COVID-19: An Overview of the Epidemiology, Clinical Features, Diagnosis, Treatment and Prevention Options in Children. Pediatr Infect Dis J. 2020;39(5):355-368. doi:10.1097/INF.0000000000002660 
medRxiv preprint doi: https://doi.org/10.1101/2021.03.17.21253610; this version posted March 17, 2021. The copyright holder for this preprint (which was not certified by peer review) is the author/funder, who has granted medRxiv a license to display the preprint in perpetuity.

All rights reserved. No reuse allowed without permission.

14. Mustafa NM, A Selim L. Characterisation of COVID-19 Pandemic in Paediatric Age Group: A Systematic Review and Meta-Analysis. J Clin Virol. 2020 Jul;128:104395. doi: 10.1016/j.jcv.2020.104395. Epub 2020 May 8. PMID: 32417675; PMCID: PMC7207144.

15. Ludvigsson JF. Systematic review of COVID-19 in children shows milder cases and a better prognosis than adults. Acta Paediatr. 2020 Jun;109(6):1088-1095. doi: 10.1111/apa.15270. Epub 2020 Apr 14. PMID: 32202343; PMCID: PMC7228328.

16. Liguoro I, Pilotto C, Bonanni M, Ferrari ME, Pusiol A, Nocerino A, et al. SARS-COV-2 infection in children and newborns: a systematic review. Eur J Pediatr. 2020 Jul;179(7):1029-1046. doi: 10.1007/s00431-020-03684-7. Epub 2020 May 18. PMID: 32424745; PMCID: PMC7234446.

17. Yoon S, Li H, Lee KH, Hong SH, Kim D, Im H, et al. Clinical Characteristics of Asymptomatic and Symptomatic Pediatric Coronavirus Disease 2019 (COVID-19): A Systematic Review. Medicina (Kaunas). 2020 Sep 15;56(9):E474. doi: 10.3390/medicina56090474. PMID: 32942705.

18. de Lusignan S, Dorward J, Correa A, Jones N, Akinyemi O, Amirthalingam G, et al. Risk factors for SARS-CoV-2 among patients in the Oxford Royal College of General Practitioners Research and Surveillance Centre primary care network: a cross-sectional study [published online ahead of print, 2020 May 15]. Lancet Infect Dis. 2020;S1473-3099(20)30371-6. doi:10.1016/S1473-3099(20)303716

19. Mao B, Liu Y, Chai YH, Jin XY, Lu HW, Yang JW, et al. Assessing risk factors for SARS-CoV-2 infection in patients presenting with symptoms in Shanghai, China: a multicentre, observational cohort study. The Lancet Digital Health, 14 May 2020. DOI:https://doi.org/10.1016/S2589-7500(20)30109-6

20. Wynants L, Van Calster B, Bonten MMJ, Riley RD, Heinze G, Schuit E, et al. Prediction models for diagnosis and prognosis of covid-19 infection: systematic review and critical appraisal. BMJ. 2020;369:m1328. Published 2020 Apr 7. doi:10.1136/bmj.m1328

21. Ho FK, Celis-Morales CA, Gray SR, Vittal Katikireddi S, Niedzwiedz CL, Hastie C, et al. Modifiable and non-modifiable risk factors for COVID-19: results from UK Biobank. medRxiv 2020; published online May 2. https://doi.org/10.1101/2020.04.28.20083295 (preprint)

22. Peng D, Zhang J, Xu Y, Liu Z, Wu P. The role of procalcitonin in early differential diagnosis of suspected children with COVID-19. medRxiv 2020.04.07.20057315; doi: https://doi.org/10.1101/2020.04.07.20057315

23. Von Elm E, Altman DG, Egger M, Pocock SJ, Gøtzsche PC, Vandenbroucke JP; STROBE Initiative. The Strengthening the Reporting of Observational Studies in Epidemiology (STROBE) statement: guidelines for reporting observational studies. Lancet 2007;370(9596):1453-7

24. Ministero della Salute. Circolare 9 March 2020, Available at http://www.trovanorme.salute.gov.it/norme/renderNormsanPdf?anno=2020\&codLeg=73669\&par te $=1 \% 20 \&$ serie $=$ null (accessed Mach 27, 20202)

25. Verdoni L, Mazza A, Gervasoni A, Martelli L, Ruggeri M, Ciuffreda M, et al. An outbreak of severe Kawasaki-like disease at the Italian epicentre of the SARS-CoV-2 epidemic: an observational cohort study [published online ahead of print, 2020 May 13]. Lancet. 2020;10.1016/S0140-6736(20)31103X. doi:10.1016/S0140-6736(20)31103-X

26. Recalcati S. Cutaneous manifestations in COVID-19: a first perspective. J Eur Acad Dermatol Venereol. 2020 Mar 26. doi: 10.1111/jdv.16387

27. Tullie L, Ford K, Bisharat M, Watson T, Thakkar H, Mullassery D, et al. Gastrointestinal features in children with COVID-19: an observation of varied presentation in eight children [published online ahead of print, 2020 May 19]. Lancet Child Adolesc Health. 2020;S2352-4642(20)30165-6. doi:10.1016/S2352-4642(20)30165-6 
medRxiv preprint doi: https://doi.org/10.1101/2021.03.17.21253610; this version posted March 17, 2021. The copyright holder for this preprint (which was not certified by peer review) is the author/funder, who has granted medRxiv a license to display the preprint in

All rights reserved. No reuse allowed without permission.

28. Whittaker A, Anson M, Harky A. Neurological Manifestations of COVID-19: A systematic review and current update. Acta Neurol Scand. 2020;142(1):14-22. doi:10.1111/ane.13266

29. Rogers JP, Chesney E, Oliver D, Pollak TA, McGuire P, Fusar-Poli P, et al. Psychiatric and neuropsychiatric presentations associated with severe coronavirus infections: a systematic review and meta-analysis with comparison to the COVID-19 pandemic [published online ahead of print, 2020 May 18]. Lancet Psychiatry. 2020;S2215-0366(20)30203-0. doi:10.1016/S22150366(20)30203-0

30. Chow EJ, Schwartz NG, Tobolowsky FA, Zacks RLT, Huntington-Frazier M, Reddy SC, et al. Symptom Screening at Illness Onset of Health Care Personnel With SARS-CoV-2 Infection in King County, Washington. JAMA. 2020;323(20):2087-2089. doi:10.1001/jama.2020.6637

31. World Health Organization Global surveillance for COVID-19 caused by human infection with COVID-19 virus. Interim Guidance. 20 March 2020. Available at https://apps.who.int/iris/handle/10665/331506 (accessed May 28, 2020)

32. Istituto superiore di Sanità. Epidemia COVID-19. Aggiornamento nazionale 20 maggio 2020. Available at https://www.epicentro.iss.it/coronavirus/bollettino/Bollettino-sorveglianza-integrataCOVID-19_20-maggio-2020.pdf (accessed May 28, 2020)

33. Wu Z, McGoogan JM. Characteristics of and Important Lessons From the Coronavirus Disease 2019 (COVID-19) Outbreak in China: Summary of a Report of 72314 Cases From the Chinese Center for Disease Control and Prevention. JAMA. 2020 Feb 24.

34. Shekerdemian LS, Mahmood NR, Wolfe KK, Riggs BJ, Ross CE, McKiernan CA, et al. Characteristics and Outcomes of Children With Coronavirus Disease 2019 (COVID-19) Infection Admitted to US and Canadian Pediatric Intensive Care Units [published online ahead of print, 2020 May 11]. JAMA Pediatr. 2020;10.1001/jamapediatrics.2020.1948. doi:10.1001/jamapediatrics.2020.1948

35. Centers for Disease Control and Prevention. COVID-19 data. Weekly Updates by Select Demographic and Geographic Characteristics. Available at https://www.cdc.gov/nchs/nvss/vsrr/covid_weekly/index.htm\#AgeAndSex (accessed June 10, 2020)

36. Centers for Disease Control and Prevention. Weekly U.S. Influnza Surveillance Report. Available at https://www.cdc.gov/flu/weekly/\#S3 (accessed June 10, 2020)

37. Burn E, You SC, Sena AG, Kostka K, Abedtash H, Abrahão MTF, et al. An international characterisation of patients hospitalised with COVID-19 and a comparison with those previously hospitalised with influnza. Preprint. medRxiv. 2020;2020.04.22.20074336. Published 2020 Apr 25. doi:10.1101/2020.04.22.20074336

38. Turner D, Huang Y, Martín-de-Carpi J, Aloi M, Focht G, Kang B, et al. Corona Virus Disease 2019 and Paediatric Inflammatory Bowel Diseases: Global Experience and Provisional Guidance (March 2020) from the Paediatric IBD Porto Group of European Society of Paediatric Gastroenterology, Hepatology, and Nutrition. J Pediatr Gastroenterol Nutr. 2020;70(6):727-733. doi:10.1097/MPG.0000000000002729

39. Boulad F, Kamboj M, Bouvier N, Mauguen A, Kung AL. COVID-19 in Children With Cancer in New York City [published online ahead of print, 2020 May 13]. JAMA Oncol. 2020;e202028. doi:10.1001/jamaoncol.2020.2028

40. Hains DS, Schwaderer AL, Carroll AE, Starr MC, Wilson AC, Amanat F, et al. Asymptomatic Seroconversion of Immunoglobulins to SARS-CoV-2 in a Pediatric Dialysis Unit [published online ahead of print, 2020 May 14]. JAMA. 2020;e208438. doi:10.1001/jama.2020.8438

41. Marlais M, Wlodkowski T, Vivarelli M, Pape L, Tönshoff B, Schaefer F, et al. The severity of COVID-19 in children on immunosuppressive medication [published online ahead of print, 2020 May 13]. 
medRxiv preprint doi: https://doi.org/10.1101/2021.03.17.21253610; this version posted March 17, 2021. The copyright holder for this preprint (which was not certified by peer review) is the author/funder, who has granted medRxiv a license to display the preprint in perpetuity.

All rights reserved. No reuse allowed without permission.

Lancet Child Adolesc Health. 2020;10.1016/S2352-4642(20)30145-0. doi:10.1016/S23524642(20)30145-0

42. Istituto superiore di Sanità. Epidemia COVID-19. Aggiornamento (appendice) nazionale 20 maggio 2020. Available at https://www.epicentro.iss.it/coronavirus/bollettino/Bolletino-sorveglianzaintegrata-COVID-19_20-maggio-2020_appendix.pdf (accessed May 28, 2020)

43. GIMBE: Comunicato stampa del 7 maggio 2020. Coronavirus: la giungla dei tamponi. Available at https://www.gimbe.org/pagine/341/it/comunicati-stampa (accessed May 11, 2019)

44. Godlee Fiona. Covid-19: Testing testing BMJ 2020; 369 :m1918

45. Wang W, Xu Y, Gao R, Lu R, Han K, Wu G, et al. Detection of SARS-CoV-2 in Different Types of Clinical Specimens. JAMA. 2020 Mar 11. doi: 10.1001/jama.2020.3786

\section{Declaration of interest}

We declare no competing interests

\section{Data Sharing}

De-identified individual participant data will be made available following completion of a data use agreement.

\section{Funding source}

None 